\title{
Effects of Mozzarella Cheese Manufactured by $S$. macedonicus LC743 on the Immune Status of Mouse
}

\author{
Seong-A Cho, Kee-Sung Kim, and Sang-Dong Lim* \\ Korea Food Research Institute, Seongnam 463-746, Korea
}

\begin{abstract}
To develop a new starter culture for Mozzarella cheese, the immunomodulatory action of Streptococcus macedonicus LC743 in male C57BL/6 mice was studied. Mice were fed for $7 \mathrm{wk}$ with feed containing 1\% Mozzarella cheese made with three kinds of starter cultures from S. macedonicus LC743 (G3), FD-DVS TCC-3 (G2) and S. macedonicus LC743 : FDDVS TCC-3(1:1) (G4) and control (feed only, G1), respectively. No significant differences in body weight gain were observed among the various groups of mice. The spleen index and thymus index were observed and no significant differences were found among the groups. The production of TNF- $\alpha$ of S. macedonicus LC743 group significantly increased compared to the control group. The production of IL- $1 \beta$ was significantly enhanced by the feeding of $S$. macedonicus LC743 group compared to the control group. In regards to the white blood cell counts, the neutrophil percentages were significantly higher in the G1 group compared to other groups. The lymphocyte percentages were significantly higher in G2, G3 and G4 groups in comparison to the control group. The results of this study may suggest that the supplementation of $S$. macedonicus LC743 can increase the cytokine production activity by the activated macrophages in mice. Based on the result of this study, it could be concluded that S. macedonicus LC743 could stimulate the immune functions of mice.
\end{abstract}

Key words: immunomodulating activity, Mozzarella cheese, S. macedonicus LC743, mouse

\section{Introduction}

The consumption of Mozzarella cheese has increased rapidly during the last 15 years, primarily because it is one of the ingredients of 'pizza' and other Italian specialities that are widely consumed all over the world. Mozzarella cheese is mainly used for its unique functional properties such as stretchability, meltability free oil formation, and browning. Under industrial conditions, selected thermophilic lactic acid bacteria cultures are used as starters in Mozzarella cheese manufacturing (Oberg et al., 1991). More recently, several trials have been made regarding the production of cheeses with probiotic bacteria as adjuncts. These trials include soft cheeses such as Cottage (Blanchette et al., 1996; Riordan and Fitzgerald, 1998), Crescenza (Gobbetti et al., 1998), Fresh (Vinderola et al., 2000) and Kariesh (Murad et al., 1998) or semi-hard cheeses like Cheddar (Dinakar and Mistry, 1994; Furtado et al., 1993; Gardiner et al., 1998;

*Corresponding author: Sang-Dong Lim, Korea Food Research Institute, Seongnam 463-746, Korea. Tel: 82-31-780-9082, Fax: 82-31-780-9160, E-mail: limsd@kfri.re.kr
Gardiner et al., 1999; Shaw and White, 1994; Stanton et al., 1998), Goat cheese (Gomes and Malcata, 1998) and Canestrato Pugliese (Corbo et al., 2001). Probiotic fresh cheese (Argentinean fresh cheese) containing L. acidophilus A9, B. bifidum A12 and L. paracasei A13 showed immunomodulating capacity in mice, providing increased phagocytic activity in the small intestine of peritoneal macrophages, after 2, 5 and $7 \mathrm{~d}$ of its ingestion. Moreover, a significant increase in the number of IgA producing cells in the large intestine after $5 \mathrm{~d}$ of administration was reported. Interaction of probiotic bacteria as bacterial antigens in the small (Peyer's patches) and large (lymphoid nodules) intestine was also observed (Medici et al., 2004). Phagocytic cells play a central role in protection against microbial infections. In addition, macrophages are concerned in antigen presentation, tissue repair and also play an important role in the regulation of immune responses (Gill, 1998). Cytokines influence the defense system of the host directly or indirectly. Soluble factors such as IL-1, IL- 6 and TNF- $\alpha$ released by monocytes have been shown to play key roles in proliferation, activation and differentiation of immune cells (Czarniecki, 1993). Also, IL-1 stimulates T-and B-cell proliferation, 
TNF- $\alpha$ has a cytotoxic effect on tumour cells (Gill, 1998). IL-1 is a major product of the stimulated monocyte and is responsible for diverse biological effects. The systemic effects of IL-1 include fever, increased circulating neutrophils, hepatic acute phase proteins, slow wave sleep, elevated insulin levels and hypotension (Dinarello, 1987). TNF- $\alpha$ is also produced by activated macrophages, fibroblasts, and many different types of cells. The regulation of TNF- $\alpha$ production is critical in the maintenance of homeostasis of the immune system and in the prevention and treatment of the immune diseases (Kang et al., 1996). IL-6 is an interleukin that acts as both a proinflammatory and anti-inflammatory cytokine. It is secreted by $\mathrm{T}$ cells and macrophages to stimulate immune response, e.g. during infection and after trauma, especially burns or other tissue damage leading to inflammation. In terms of host response to a foreign pathogen during infection, IL6 has been shown, in mice, to be required for resistance against the bacterium, Streptococcus pneumoniae (van der Poll et al., 1997).

The objective of this study is to investigate the immunomodulatory potential of oral administration of Mozzarella cheese manufactured by S. macedonicus LC743 in mice.

\section{Materials and Methods}

\section{Preparation of Mozzarella cheese}

Pasteurised milk was used on each occasion for the manufacture of Mozzarella cheese in three (including the control) cheese treatments. The first treatment was the control Mozzarella cheese (cheese C1), with the starter culture of FD-DVS TCC-3 (mixed culture of Lactobacillus bulgaricus and Streptococcus thermophilus, CHR. HANSEN A/S), 2\% (v/v). For the second treatment of Mozzarella cheese (cheese $\mathrm{C} 2$ ), $2 \%$ (v/v, $2 \times 10^{7}$ cells) of S. macedonicus LC743. For the third treatment of Mozzarella cheese (cheese C3), $2 \times 10^{7}$ cells of strain S. macedonicus LC743, were incorporated with FD-DVS TCC-3 by the ratio of $1: 1$.

\section{Animal and feeding procedure}

SPF C57BL/6 mice, weighted $20.0 \pm 2.0$ g, were provided by Koatech (Korea), were randomly divided into four groups $(n=15) \mathrm{G} 1, \mathrm{G} 2, \mathrm{G} 3$ and G4. The animal group G1: the control group, fed ad libitum a diet (Table 1) without cheese supplementation, G2: fed ad libitum a diet containing the cheese (1\%) made with TCC-3, G3: fed ad libitum a diet containing the cheese (1\%) made
Table 1. Formulation of basal diet (AIN-76 purified diet)

\begin{tabular}{lc}
\hline \multicolumn{1}{c}{ Ingredient } & Contents (\%) \\
\hline Casein (feed grade CP 85\%) & 20 \\
Corn starch & 15 \\
Sucrose & 45 \\
Cellulose (fiber) & 5 \\
Tallow & 5 \\
Sallower oil & 5 \\
DL-methionine & 0.3 \\
AIN-vitamin mixture ${ }^{1)}$ & 1.0 \\
AIN-mineral mixture & 3.5 \\
Choline bitartrate & 0.2 \\
\hline \multicolumn{1}{c}{ Total } & 100 \\
\hline
\end{tabular}

${ }^{1)}$ Contained per kg mixture; Thiamin·HCl $600 \mathrm{mg}$, Riboflavin 600 mg, Pyridoxine $\cdot \mathrm{HCl} 700 \mathrm{mg}$, Nicotinicacid 3 g, Vit. A 400,000 IU (Retinyl acetate), Vit. E (dL- $\alpha$-Tocopheryl acetate) 5,000 IU, Vit. $\mathrm{D}_{3} 2.5 \mathrm{mg}$, Vit. K $5.0 \mathrm{mg}$ and sucrose

${ }^{2)}$ Contained per kg mixture; $\mathrm{CaHPO}_{4} 500 \mathrm{~g}, \mathrm{NaCl} 74 \mathrm{~g}, \mathrm{~K}_{3} \mathrm{C}_{6} \mathrm{O}_{7}$ $\cdot \mathrm{H}_{2} \mathrm{O} 220 \mathrm{~g}, \mathrm{~K}_{2} \mathrm{SO}_{4} 52 \mathrm{~g}, \mathrm{MgO} 24 \mathrm{~g}, 48 \mathrm{Mn} 3.5 \mathrm{~g}, 17 \% \mathrm{Fe} 6.0 \mathrm{~g}$, $70 \% \mathrm{Zn} 1.6 \mathrm{~g}, 53 \% \mathrm{Cu} 0.3 \mathrm{~g}, \mathrm{KIO}_{3} 0.01 \mathrm{~g}, \mathrm{CrK}\left(\mathrm{SO}_{4}\right)_{2} \cdot 12 \mathrm{H}_{2} \mathrm{O}$ $0.55 \mathrm{~g}$ and sucrose

with S. macedonicus LC743 and G4: fed ad libitum a diet containing the cheese $(1 \%)$ made with TCC-3 and $S$. macedonicus LC743 (1:1). Three animals were housed in a plastic cage with wood chip bedding in an animal room with a $12 \mathrm{~h}$ light and $12 \mathrm{~h}$ dark condition at room temperature $\left(20 \pm 2^{\circ} \mathrm{C}\right)$.

\section{Body weight and spleen, thymus index}

Body weight was measured once every week. Seven weeks after experimental diet administration the animals were sacrificed, their body, spleen and thymus weights recorded, and the spleen and thymus index for each individual mouse was calculated as follows:

Spleen index $=$ spleen weight $/$ weight $\times 100$

Thymus index $=$ thymus weight $/$ weight $\times 100$

\section{Collection of serum and peritoneal macrophages}

Blood was collected from the mice after 7 wk of feeding trial. Serum was then separated from the blood by centrifugation at $2000 \mathrm{~g}$ for $10 \mathrm{~min}$ and stored at $-20^{\circ} \mathrm{C}$ until cytokines is assayed. Serum was used to estimate the presence of IL- $1 \beta$, IL- 6 and TNF- $\alpha$ using mouse IL$1 \beta$, IL- 6 and TNF- $\alpha$ ELISA kits (R\&D systems, USA).

Peritoneal macrophages were obtained using RPMI1640 medium from mouse peritoneal. The macrophages were washed with RPMI-1640 medium and placed in a density of $1 \times 10^{6}$ cells per well in 96 well plate. Cells were incubated at $37^{\circ} \mathrm{C}$ in $5 \% \mathrm{CO}_{2}$ for $2 \mathrm{~h}$ and plated on 
confluent monolayer. After $2 \mathrm{~h}$, non-adherent cells was washed and removed and then suspended by RPMI 1640 supplemented with $1 \%$ fetal bovine serum (1\% FBS/ RPMI).

\section{Cytokine assay (IL-1 $\beta$, IL-6 and TNF- $\alpha$ )}

Serum was used to estimate the presence of IL-1 $\beta$, IL6 and TNF- $\alpha$ using mouse IL- $1 \beta$, IL- 6 and TNF- $\alpha$ ELISA kits according to the manufacturer's instructions.

The peritoneal macrophages were suspended in $900 \mathrm{uL}$ of RPMI 1640 supplemented with 1\% fetal bovine serum ( $1 \% \mathrm{FBS} / \mathrm{RPMI}$ ) and added $100 \mu \mathrm{L}$ of FBS each well and incubated at $37^{\circ} \mathrm{C}$ in $5 \% \mathrm{CO}_{2}$ for $48 \mathrm{~h}$. After incubation, the culture supernatants $(100 \mu \mathrm{L})$ were used to estimate the presence of IL-1 $\beta$, IL- 6 and TNF- $\alpha$ using mouse IL$1 \beta$, IL- 6 and TNF- $\alpha$ ELISA kits according to the manufacturer's instructions.

\section{Differential white blood cell count and tissue prep- aration}

White blood cells (WBC) were enumerated on a cell counter. Differential WBC counts were performed on Wright's-stained smears.

All organs were fixed in $10 \%$ formalin, embedded in paraffin, and sectioned at 2-3 $\mu \mathrm{m}$. Sections were stained with hematoxylin and eosin and examined in the light microscope.

\section{Results and Discussion}

\section{Body weight and spleen, thymus index}

The mice were fed a diet containing cheese made with S. macedonicus LC743, FD-DVS TCC-3, LC743 and FD-DVS TCC-3 (1:1) and a diet without cheese supplementation everyday for seven weeks. For the basic data, body weight and physiological parameters such as spleen index and thymus index were observed. No significant differences of body weight gain were recorded in various groups of animals (Fig. 1). The spleen index was higher the G1 (control group) than the other groups. The thymus index was higher the G3 treated with S. macedonicus LC743 than the other groups. But, the spleen index and the thymus index were observed no significant differences (Fig. 2).

\section{Cytokine assay (IL-1 $\beta$, IL-6 and TNF- $\alpha$ )}

The macrophages phagocytose the infected cells, preluding the production of antibodies, cytokines and chemokines to modulate immune responses (Morrissette et al.,

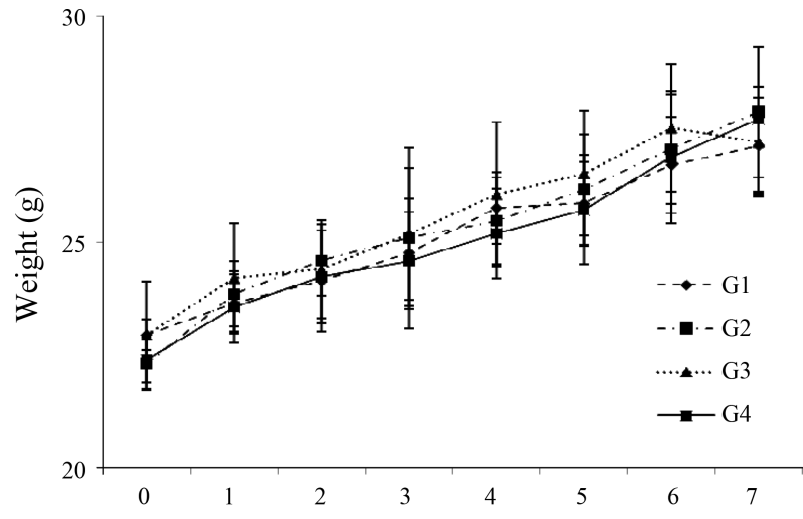

Fig. 1. Body weight changes of C57BL/6 mice fed experimental diets for 7 wk. G1, Control group without cheese supplementation; G2, Diet group containing the cheese (1\%) made with TCC-3 (Chr. Hansen A/S); G3, Diet group containing the cheese $(1 \%)$ made with $S$. macedonicus LC743; G4, Diet group containing the cheese (1\%) made with TCC-3 and S. macedonicus LC743

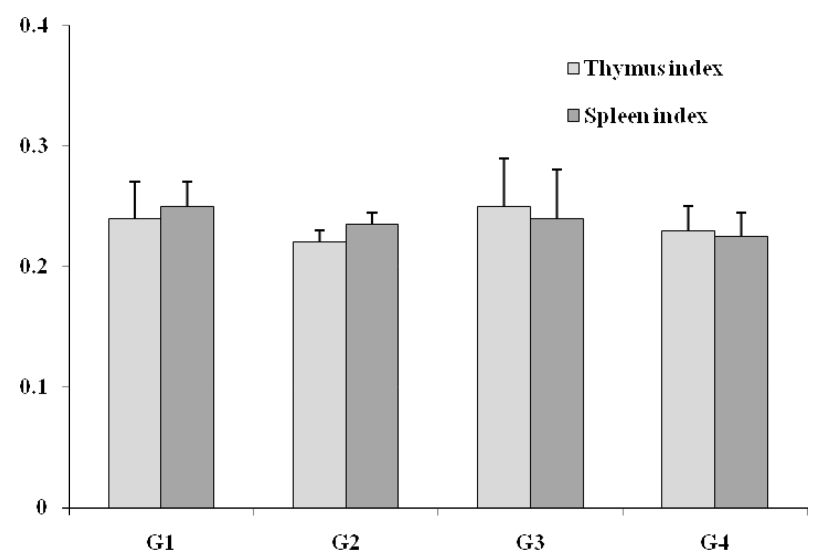

Fig. 2. Lymphatic organ index changes of $\mathrm{C57BL} / 6$ mice fed experimental diets for $7 \mathbf{w k}$. G1, Control group without cheese supplementation; G2, Diet group containing the cheese (1\%) made with TCC-3 (Chr. Hansen A/S); G3, Diet group containing the cheese (1\%) made with $S$. macedonicus LC743; G4, Diet group containing the cheese (1\%) made with TCC-3 and S. macedonicus LC743

1999). IL-1 $\beta$, IL-6 and TNF- $\alpha$ are excellent indicators of macrophage activation and play an important role in killing of tumor cells (Mantovani et al. 1992). Fig. 3 showed that IL- $1 \beta$, IL- 6 and TNF- $\alpha$ production by mice peritoneal macrophages treated with cheese containing $S$. macedonicus LC743, TCC-3, S. macedonicus LC743 + TCC-3 (1:1) and without cheese supplement. The IL-1 $\beta$ level was significantly higher in G2, G3 and G4 treated with cheese supplement than control group. The TNF- $\alpha$ level was significantly higher in G3 and G4 treated with cheeses containing S. macedonicus 743 and S. macedonicus $\mathrm{LC} 743+$ TCC-3 (1:1) than G1 group. The IL-6 level was signifi- 


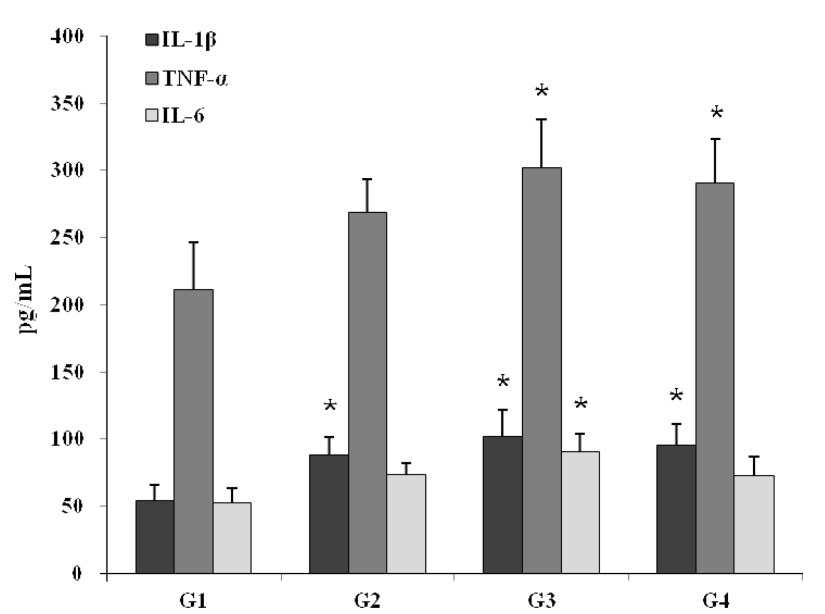

Fig. 3. IL-1 $\beta$, TNF- $\alpha$, IL-6 production by peritoneal macrophages of $\mathrm{C} 57 \mathrm{BL} / 6$ mice fed experimental diets for 7 wk. *Significant difference from control $(p<0.05)$; G1, Control group without cheese supplementation; G2, Diet group containing the cheese (1\%) made with TCC-3 (Chr. Hansen A/S); G3, Diet group containing the cheese (1\%) made with $S$. macedonicus LC743; G4, Diet group containing the cheese (1\%) made with TCC-3 and S. macedonicus LC743

cantly higher in G3 treated with cheeses containing $S$. macedonicus 743 than other groups. Fig. 4 showed that the serum IL-1 $\beta$, IL- 6 and TNF- $\alpha$ concentration in mice treated with cheese containing S. macedonicus LC743 and TCC-3. The IL-1 $\beta$ level was observed no significant differences in all group. G3 group treated with cheese containing S. macedonicus LC743 showed the highest production of TNF- $\alpha$ compared to the other groups. The IL-6 level was significantly the higher treated with $S$. macedonicus $\mathrm{LC} 743$ and $S$. macedonicus LC743 + TCC3 (1:1) group than the control group. This result demonstrated that the ingestion of the cheeses containing $S$. macedonicus LC743 and S. macedonicus LC743 + TCC3 (1:1) could be able to activate macrophages.

\section{Differential white cell count and tissue examination}

In differential white blood cell counts, the neutrophils

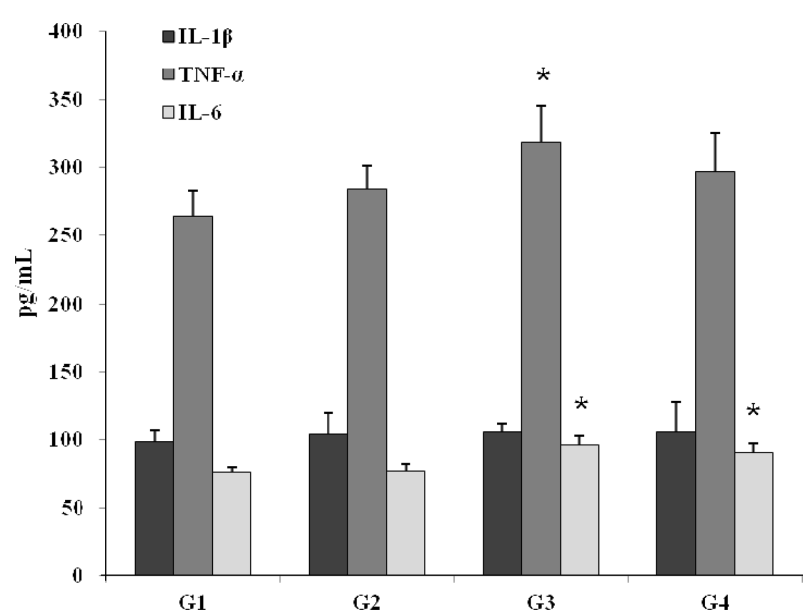

Fig. 4. IL-1 $\beta$, TNF- $\alpha$, IL-6 concentration in serum of C57BL/ 6 mice fed experimental diets for 7 wk. ${ }^{*}$ Significant difference from control $(p<0.05)$; G1, Control group without cheese supplementation; G2, Diet group containing the cheese (1\%) made with TCC-3 (Chr. Hansen A/ S); G3, Diet group containing the cheese (1\%) made with S. macedonicus LC743; G4, Diet group containing the cheese (1\%) made with TCC-3 and S. macedonicus LC743

percentages were significantly higher in G1 group than other groups. The lymphocytes percentages were significantly higher in G2, G3 and G4 treated with cheeses containing TCC-3, S. macedonicus 743 and S. macedonicus LC743 + TCC-3 (1:1) than control group. The monocytes, eosinophils and basophils percentages were observed no significant differences in all groups (Table 2). Fig. 5 showed result of photograph and light microscopic findings in the male C57BL/6 mice spleen of experimental diets and control group. The spleen of control group mice was appeared normal (A). The treated mice showed lightly lymphocyte depletion and enlargement of germinal center in spleen (B).

Based on the result of this study, it could be concluded that the S. macedonicus LC743 could stimulate the immune functions of mice.

Table 2. Differential white cell counts of C57BL/6 mice fed experimental diets for $7 \mathrm{wk}(\%)$

\begin{tabular}{cccccc}
\hline \hline Group & Neutrophils & Lymphocytes & Monocytes & Eosinophils & Basophils \\
\hline G1 & $13.14( \pm 5.84)^{\mathrm{a}}$ & $84.16( \pm 7.65)^{\mathrm{b}}$ & $1.46( \pm 0.62)$ & $0.68( \pm 0.36)$ & $0.56( \pm 0.48)$ \\
G2 & $11.78( \pm 3.26)^{\mathrm{b}}$ & $86.12( \pm 4.04)^{\mathrm{a}}$ & $1.14( \pm 0.25)$ & $0.52( \pm 0.45)$ & $0.44( \pm 0.55)$ \\
G3 & $11.70( \pm 6.52)^{\mathrm{b}}$ & $85.82( \pm 7.64)^{\mathrm{a}}$ & $1.46( \pm 0.82)$ & $0.58( \pm 0.24)$ & $0.44( \pm 0.55)$ \\
G4 & $11.75( \pm 3.33)^{\mathrm{b}}$ & $85.89( \pm 3.06)^{\mathrm{a}}$ & $1.46( \pm 0.54)$ & $0.41( \pm 0.63)$ & $0.49( \pm 0.68)$ \\
\hline
\end{tabular}

Values are mean \pm S.D.

${ }^{\mathrm{a}-\mathrm{b}}$ Means within a same column with different superscripts are significantly different $(p<0.05)$.

G1, Control group without cheese supplementation; G2, Diet group containing the cheese (1\%) made with TCC-3 (Chr. Hansen A/S); G3, Diet group containing the cheese (1\%) made with S. macedonicus LC743; G4, Diet group containing the cheese (1\%) made with TCC-3 and S. macedonicus LC743 


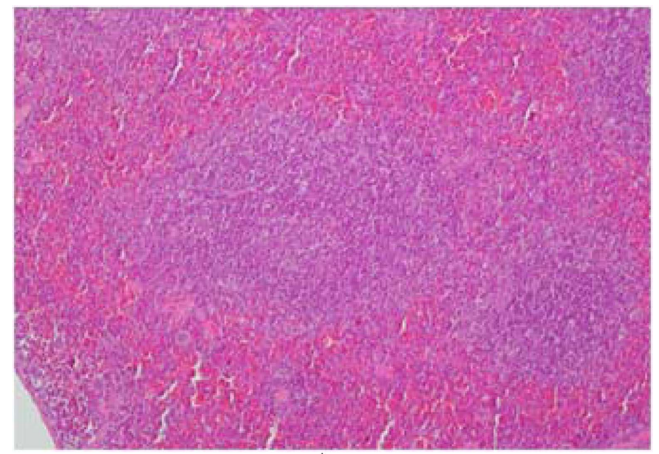

A

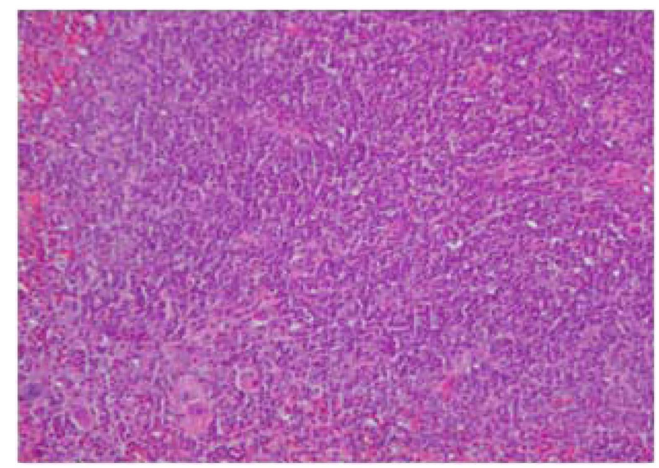

B

Fig. 5. Photograph and light microscopic findings in the male C57BL/6 mice spleen from control groups (A) and experimental diets (B) (Hematoxylin \& Eosin; Magnification: $\times 200)$.

\section{Acknowledgement}

The study was financially supported by Technology Development Program for Agriculture and Forestry Ministry for Food, Agriculture, Forestry and Fisheries, 2010.

\section{References}

1. Blanchette, L., Roy, D., Bélanger, G., and Gauthier, S. F. (1996) Production of cottage cheese using dressing fermented by bifidobacteria. J. Dairy Sci. 79, 8-15.

2. Corbo, M., Albenzio, M., De Angelis, M., Sevi, A., and Gobbetti, M. (2001) Microbiological and biochemical properties of Canestrato Pugliese hard cheese supplemented with bifidobacteria. J. Dairy Sci. 84, 551-561.

3. Czarniecki, C. A. (1993) The role of tumor necrosis factor in viral disease. Antiviral Res. 22, 223-258.

4. Dinakar, P. and Mistry, V. V. (1994) Growth and viability of Bifidobacterium bifidum in Cheddar cheese. J. Dairy Sci. 77, 2854-2864.

5. Dinarello, C. A. (1987) The biology of interleukin 1 and comparison to tumor necrosis factor. Immuno. Letters. 16, 227-232.

6. Furtado, M. M., Partridge, J. A., and Ustunol, Z. (1993) Ripening characteristics of reduced fat cheddar cheese using heat-shocked and live Lactobacillus casei as adjunt culture.
Abstract D28. J. Dairy Sci. 76, 101.

7. Gardiner, G., Ross, R., Collins, J., Fitzgerald, G., and Stanton, C. (1998) Development of a probiotic Cheddar cheese containing human-derived Lactobacillus paracasei strains. Appl. Environ. Microbiol. 64, 2192-2199.

8. Gardiner, G., Stanton, C., Lynch, P., Collins, J., Fitzgerald, G., and Ross, R. (1999) Evaluation of Cheddar cheese as a food carrier for delivery a probiotic strain to the gastrointestinal tract. J. Dairy Sci. 82, 1379-1387.

9. Gill, H. S. (1998) Stimulation of the immune system by lactic cultures. Int. Dairy. J. 8, 535-544.

10. Gobbetti, M., Corsetti, A., Smacchi, E., Zocchetti, A., and De Angelis, M. (1998) Production of Crescenza cheese by incorporation of bifidobacteria. J. Dairy Sci. 81, 37-47.

11. Gomes, A. M. P. and Malcata, F. X. (1998) Development of probiotic cheese manufactured from goat milk. J. Dairy Sci. 81, 1492-1507.

12. Kang, H. S., Kim, Y. H., Lee, C. S., Lee, J. J., Choi, I. P., and Pyun, K. H. (1998) Suppression of interleukin-1 and tumor necrosis factor- $\alpha$ production by acanthoic acid, (-)-pimara9(11), 15-dien-19-oic acid, and its antifibrotic effects in vivo. Cell. Immunol. 170, 212-221.

13. Mantovani, A., Bottazzi, B., Colotta, F., Sozzani, S., and Ruco, L. (1992) The origin and function of tumor-associated macrophages. Immunol. Today 13, 265-270.

14. Medici, M., Vinderola, C. G., and Perdigón, G. (2004) Gut mucosal immunomodulation by probiotic fresh cheese. Int. Dairy J. 14, 611-618.

15. Morrissette, N., Gold, E., and Aderem, A. (1999) The macrophage-a cell for all seasons. Trends Cell Biol. 9, 199-201.

16. Murad, H. A., Sadek, Z. I., and Fathy, F. A. (1998) Production of bifidus Kariesh cheese. Deutsche Lebensmittel-Rundschau, 94, 409-412.

17. Oberg, C. J., Wang, A., Moyes, L. V., Brown, R. J., and Richardson, G. H. (1991) Effects of proteolytic activity of thermolactic cultures on physical properties of Mozzarella cheese. J. Dairy Sci. 74, 389-397.

18. Riordan, K. O. and Fitzgerald, G. F. (1998) Evaluation of bifidobacteria for the production of antimicrobial compounds and assessment of performance in cottage cheese at refrigeration temperature. J. Appl. Microbiol. 85, 103-114.

19. Shaw, S. K. and White, C. H. (1994) Survival of bifidobacteria in reduced fat Cheddar cheese. J. Dairy Sci. 77, 4.

20. Stanton, C., Gardiner, G., Lynch, P. B., Collins, J. K., Fitzgerald, G., and Ross, R. P. (1998) Probiotic cheese. Int. Dairy J. 8, 491-496.

21. van der Poll, T., Keogh, C. V., Guirao, X., Buurman, W. A., Kopf, M., and Lowry, S. F. (1997) Interleukin-6 gene-deficient mice show impaired defense against pneumococcal pneumonia. J. Infect. Dis. 176, 439-444.

22. Vinderola, C. G., Prosello, W., Ghiberto, D., and Reinheimer, J. (2000) Viability of probiotic (Bifidobacterium, Lactobacillus acidophilus and Lactobacillus casei) and nonprobiotic microflora in argentinian fresh cheese. J. Dairy Sci. 83, 1905-1911.

$\overline{\text { (Received 2011.11.25/Revised 2012.1.5/Accepted 2012.1.10) }}$ 